Foss. Rec., 21, 213-221, 2018

https://doi.org/10.5194/fr-21-213-2018

(C) Author(s) 2018. This work is distributed under

the Creative Commons Attribution 4.0 License.

\title{
Marine microorganisms as amber inclusions: insights from coastal forests of New Caledonia
}

\author{
Alexander R. Schmidt ${ }^{1}$, Dennis Grabow ${ }^{1}$, Christina Beimforde ${ }^{1}$, Vincent Perrichot $^{2}$, Jouko Rikkinen ${ }^{3,4}$, \\ Simona Saint Martin ${ }^{5}$, Volker Thiel ${ }^{1}$, and Leyla J. Seyfullah ${ }^{1}$ \\ ${ }^{1}$ Department of Geobiology, University of Göttingen, Göttingen, Germany \\ ${ }^{2}$ Univ. Rennes, CNRS, Géosciences Rennes - UMR 6118, Rennes, France \\ ${ }^{3}$ Finnish Museum of Natural History, University of Helsinki, Helsinki, Finland \\ ${ }^{4}$ Faculty of Biological and Environmental Sciences, University of Helsinki, Helsinki, Finland \\ ${ }^{5}$ Muséum National d'Histoire Naturelle, Département Origines et Evolution, UMR 7207 CR2P \\ (MNHN CNRS-SU), Paris, France
}

Correspondence: Alexander R. Schmidt (alexander.schmidt@geo.uni-goettingen.de)

and Leyla J. Seyfullah (leyla.seyfullah@geo.uni-goettingen.de)

Received: 2 May 2018 - Revised: 6 July 2018 - Accepted: 10 July 2018 - Published: 29 August 2018

\begin{abstract}
Marine microorganisms trapped in amber are extremely rare in the fossil record, and the few existing inclusions recovered so far originate from very few pieces of Cretaceous amber from France. Marine macroscopic inclusions are also very rare and were recently described from Cretaceous Burmese amber and Early Miocene Mexican amber. Whereas a coastal setting for the amber source forests is generally proposed, different scenarios have been suggested to explain how these marine inclusions can become trapped in a resin of terrestrial origin. These scenarios include an introduction of marine organisms (i) through high tides, (ii) from storms and resulting in flooding of the littoral/estuarine forest floor, (iii) in resin dropped into the sea in mangrovetype settings, or (iv) by wind and sea spray. We investigated the possibility of a wind-driven introduction of marine microorganisms into tree resins using modern coastal conifer forests with the highly resinous Cook pine (Araucaria columnaris) in New Caledonia as a model for the Cretaceous amber forests from France. By exposing fresh resin surfaces on the seaward side of the trees and the collection of older in situ resins, we confirmed that marine microorganisms can become trapped on sea-exposed resin, along with remnants from terrestrial organisms, and salt crystals. We suggest that, for cases where only a few marine inclusions are discovered in an amber deposit, an origin from aeolian background deposition is feasible. However, a more energetic but possibly still aeolian event is likely needed to explain the high num-
\end{abstract}

bers of marine microorganisms embedded in pieces of Cretaceous amber from France.

\section{Introduction}

Amber, fossil tree resin, is renowned as an archive of terrestrial arthropods, plants and fungi. Occasionally even organisms that typically occur in freshwater habitats are recorded in amber (e.g. amphipods, Coleman, 2004; testate amoebae, Schmidt et al., 2010; diving beetles, Gómez and Damgaard, 2014). It has been shown that fresh resin flowing into limnetic waters may trap limnetic microorganisms such as algae and testate amoebae and even aquatic arthropods (Schmidt and Dilcher, 2007). Marine microorganisms occur sometimes as contaminants on the surface of, and in fissures reaching into, amber pieces, if the amber-bearing strata were exposed in the tidal zone or if amber was washed ashore after floating in seawater (e.g. Galippe, 1920; Girard et al., 2009a). However, Girard et al. (2008, 2009b, c) and Masure et al. (2013) reported rare marine microfossils (diatoms, radiolarians, dinoflagellates, sponge spicules, a foraminifer and a sea urchin larval (echinopluteus) spine) that were entirely surrounded by solid amber, not merely trapped in fissures as contaminants, from latest Albian to earliest Cenomanian (Cretaceous) amber deposits in Charentes, southwestern France (at Archingeay and La Buzinie) (Fig. 1a). Additionally, Saint 

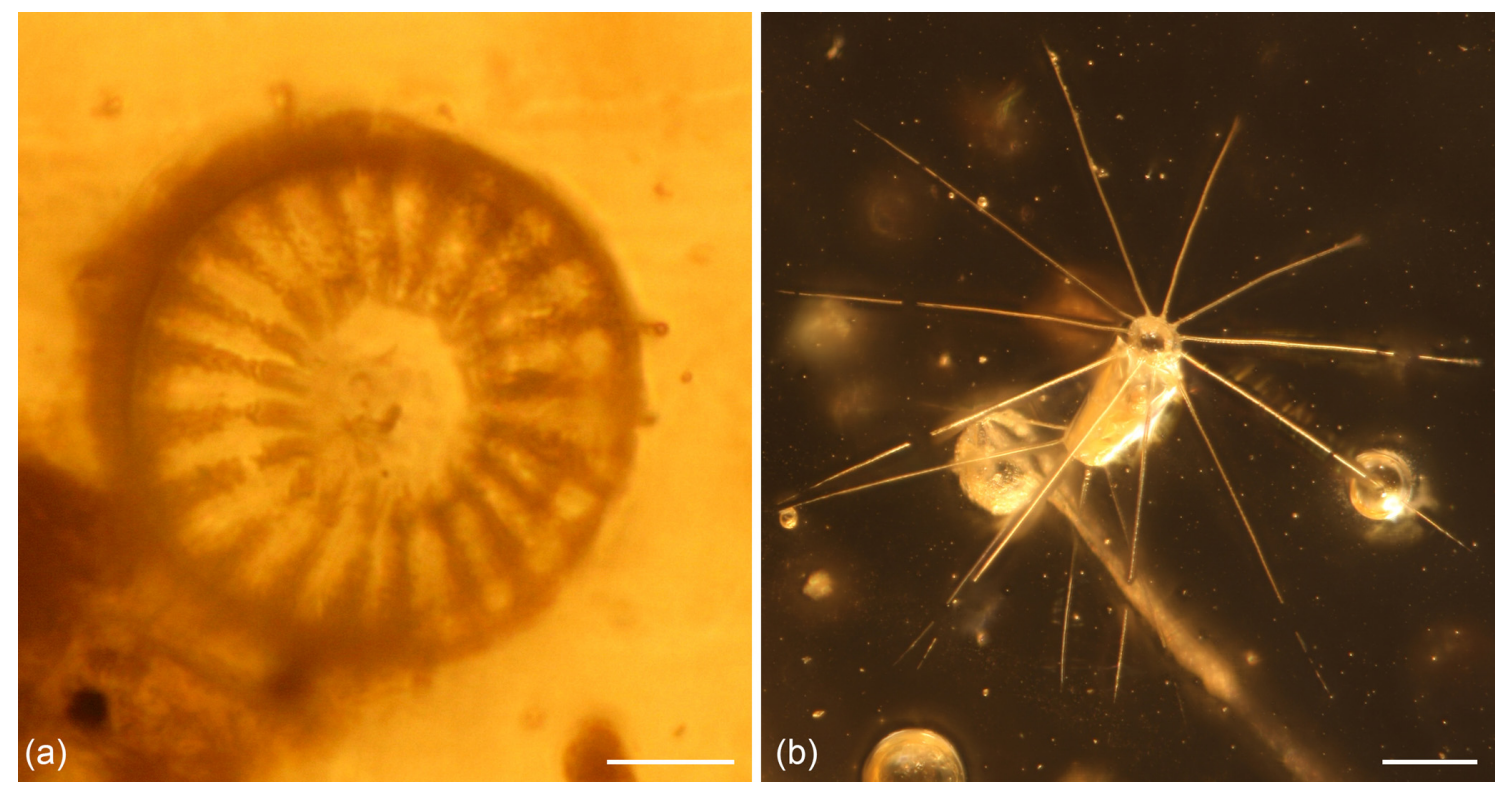

Figure 1. Inclusions of fossil diatoms from Cretaceous amber of France. (a) Representative of the order Thalassiosirales from Albian amber of Archingeay/Les Nouillers in Charente-Maritime, southwestern France. (b) Representative of the extant genus Corethron (order Corethrales) from Turonian amber of La Garnache in Vendée, northwestern France. Scale bars: $10 \mu \mathrm{m}$ (a) and $100 \mu \mathrm{m}$ (b).

Martin et al. (2015) reported marine planktonic diatoms inside amber from an amber deposit in Vendée, northwestern France (Fig. 1b), now dated as Turonian (Cretaceous) in age (Néraudeau et al., 2017). In these very few instances, non-marine organisms have also been found along with marine remains, such as isopods and tanaids (crustacea). Most tanaidaceans are marine but those in Charentese (and also Spanish) amber have been interpreted as semi-aquatic, living in moist litter, and among the isopods both fully terrestrial (Oniscidea) and semi-aquatic (Ligiidae) representatives were reported (Sánchez-García et al., 2014, 2016), strengthening the case for a moist "litter amber" (Perrichot, 2004; Perrichot et al., 2005) being preserved that had a marine influence. This apparently paradox co-occurrence has led to the idea that a resinous coastal forest in the vicinity of the marine realm is necessary to produce amber containing both terrestrial and marine inclusions (e.g. Perrichot et al., 2005; Solórzano Kraemer et al., 2014). Indeed, a particular amber piece (ARC 115) from the Charentes amber even revealed terrestrial, limnetic and marine inclusions, so a littoral or estuarine forest, receiving some freshwater input, was envisaged (see Perrichot and Girard, 2009). Recently, a marine macroscopic inclusion (ostracod) was reported from inside Cenomanian (Cretaceous) Burmese amber, and a bay, lagoonal or estuarine setting has been proposed for this deposit (Xing et al., 2018).

Tanaidaceans have been reported from a particular Mexican amber and may represent marine macroinclusions (Heard et al., 2018). The Early Miocene Mexican amber with marine-influenced inclusions was found in collections from only one particular area: the Campo La Granja amber mines in the Chiapas area, southeastern Mexico. This amber is much younger and was produced by a relative of the living angiosperm Hymenaea L., in contrast to the older Cretaceous gymnosperm-dominated amber-bearing forests described above. The distinctive layered Mexican amber with sandy layers inside has been interpreted to originate in a tidally influenced estuarine or mangrove setting (Solórzano Kraemer, 2010; Serrano-Sánchez et al., 2015), where the inclusions of predominantly estuarine crustaceans including ostracods, isopods, copepods and crabs are thought to be transported by tides and/or floods to ponds near or at the base of the resin-producing trees (Solórzano Kraemer, 2010; Serrano-Sánchez et al., 2015; Huys et al., 2016; MatzkeKarasz et al., 2017; Heard et al., 2018).

However, it remains unclear what precise situation is needed to produce amber inclusions of marine microorganisms. Different scenarios have been proposed: a littoral forest setting (Perrichot, 2004), a resinous mangrove-like setting (Perrichot et al., 2007), or a temporary marine influence on a nearby resinous forest (Girard et al., 2009). It has been suggested that the French Cretaceous resin-producing tree species grew in a mosaic of marine-influenced environments including estuarine, mangrove and limnetic areas (Perrichot, 2004; Perrichot et al., 2007, 2010). The marine microorganisms could have been entrapped by liquid resin dropping directly from the mangroves into the sea, or they were transported to the forest floor, perhaps by sea spray or high tides, and were then engulfed in resin there. It is not clear whether the introduction of these inclusions was solely 

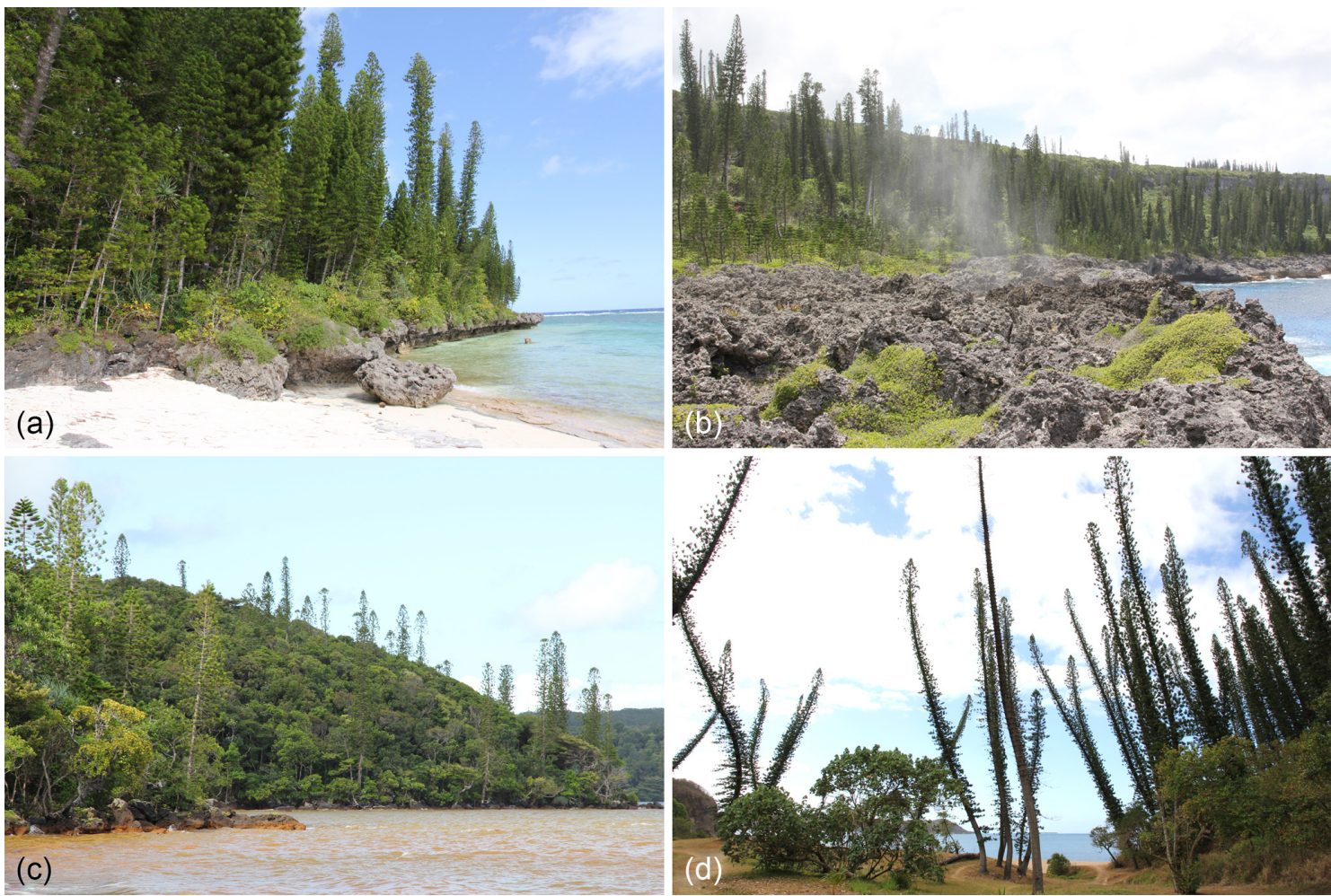

Figure 2. Observation sites where the highly resinous Araucaria columnaris forests are found at the coast in New Caledonia. Note in (b) the sea spray (white mist in centre of photograph) drifting towards the trees. (a) and (b) Maré, (c) Port Boisé, (d) Bourail.

due to the wind under normal conditions. Dried organic matter entrapped with the marine microinclusions between resin flows led Girard et al. (2008) to suggest that these were particles from a beach that were blown into the nearby forest under normal conditions. Masure et al. (2013) documented two particular Charentes amber pieces showing layered marine microinclusions (ARC 76 and ARC 130). In a layer containing marine dinoflagellates, either ground-dwelling arthropods or dipterous insects were also found randomly trapped together on the same surface. The authors argued that the layered structure indicated an origin on the aerial parts of the tree where successive resin flows engulfed the entrapped organisms and then subsequently formed the layered amber pieces. Successive resin flows exuded into water do not form such layered structures but instead form separate pillow-like resin bodies, due to the hydrophobicity of resin (Schmidt and Dilcher, 2007). It is also possible that higher-energetic events such as cyclones or tsunamis led to seawater flooding the resinous coastal forest and depositing the marine microorganisms there to become trapped in resin.

We undertook experimental fieldwork to test how marine microorganisms could become trapped and fossilised in amber in a nearshore environment. To best mimic this nearshore palaeoenvironment envisaged for the French Cretaceous amber forests entrapping marine inclusions (e.g. Perrichot, 2004; Perrichot et al., 2005, 2007; Solórzano Krae- mer et al., 2014; Sánchez-García et al., 2016), we focused on today's Araucariaceae conifer forests on the New Caledonian coast as these are highly resinous forests. Additionally, the palaeobotanical evidence shows that the Cretaceous amber forests of France and Myanmar were often dominated by araucarian conifers, along with cupressaceous and the extinct cheirolepidiaceous conifers that produced the resin (Perrichot et al., 2010; Nohra et al., 2015).

\section{Materials and methods}

\subsection{Locality and species choice}

To most closely represent the likely palaeoenvironment of the French Cretaceous amber, we focused on coastal forests dominated by Araucaria columnaris Hook. (Cook pine) in New Caledonia (Fig. 2). This species is a highly resinous extant member of the Araucariaceae, the family for which there is palaeobotanical evidence in the Charentes amber deposit (Perrichot et al., 2010; Nohra et al., 2015). For the Vendée amber deposit, a cupressaceous origin has been suggested (Néraudeau et al., 2017), but these conifers are not highly resinous today. Despite this, the source trees were part of a coastal mixed forest with araucarian trees, so the Araucaria columnaris model can probably also be applied for this amber. In November, 2011, we observed three coastal forest lo- 

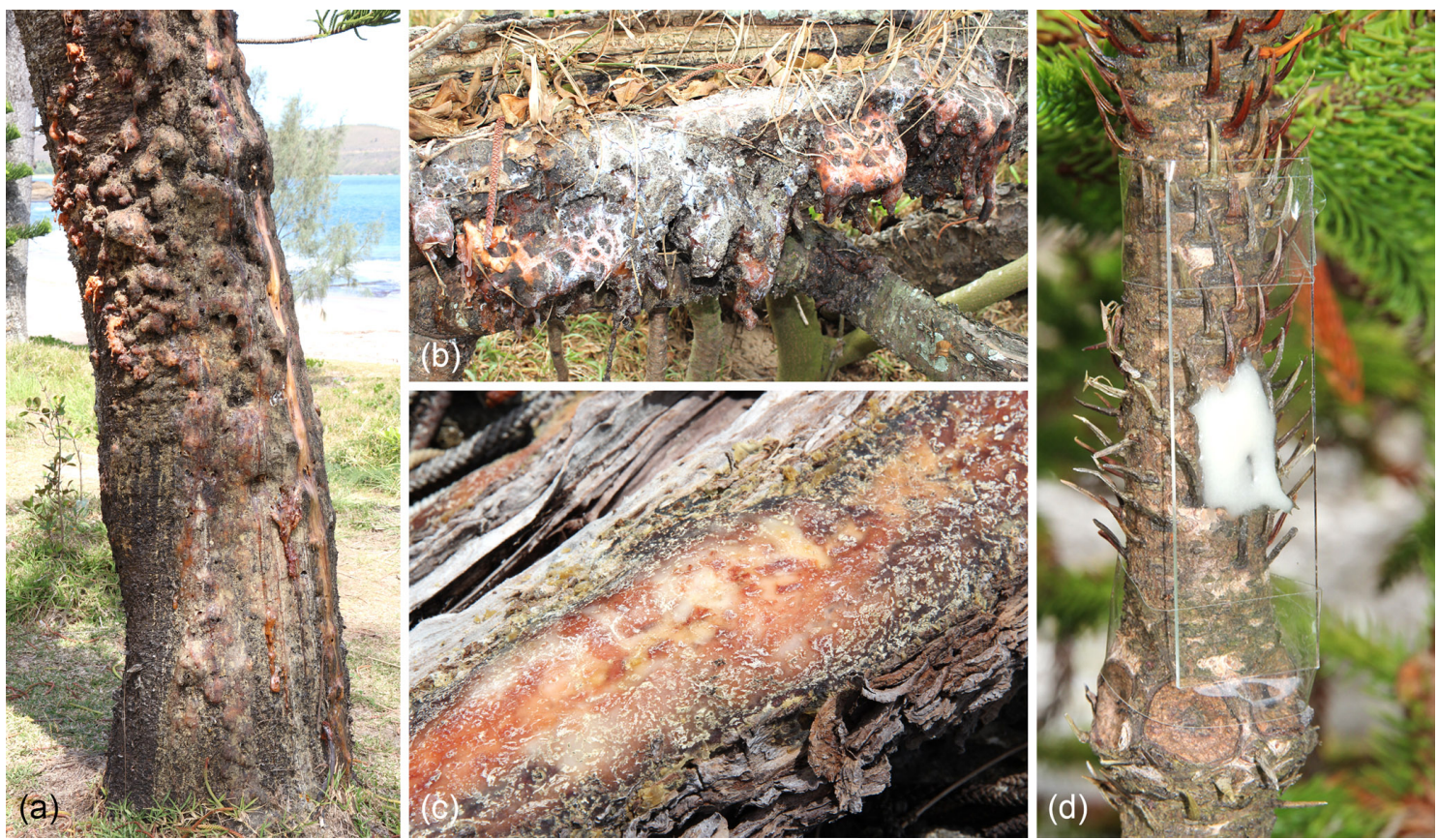

Figure 3. Resin production in coastal Araucaria columnaris forests in New Caledonia. (a) A. columnaris with extensive resin outpouring due to wind rock causing mechanical damage to the trunk. (b) Massive resin production from a root exposed due to soil erosion. (c) Resin production of an abraded and exposed root. (d) Experimental fresh resin exposure on slides lightly fixed to A. columnaris trees using sticky tapes, facing the sea.

cations in New Caledonia: the first at the northern rim of the Baie des Tortues, south of Bourail, the second south of Port Boisé on Grande Terre, and the third on the southern coast of the island of Maré (Fig. 2). The forests are all quite open and exposed to the sea (Fig. 2). Under normal calm conditions, wind-driven sea spray reaches the rim of the Araucaria columnaris forests that are situated directly at the coast (Fig. 2b).

\subsection{Fresh resin exposure to sea spray}

Thin films of the tree's fresh resin were smeared over the surface of 17 glass microscopic slides $(76 \times 26 \mathrm{~mm}$, Carl Roth $\mathrm{GmbH}$, Karlsruhe) using a scalpel. Immediately, the slides were vertically exposed with the resin side outwards and clean side of the slide against the tree bark, on the seaward side of young Araucaria columnaris trees (Fig. 3d), at distances no more than $5 \mathrm{~m}$ from the sea. The resinous slides were fixed in place at roughly the height that the resin was found. Sticky tape was used to adhere the slides for 13 days ensuring a good seaward exposure until the fresh resin dried, avoiding any damage to the trees under observation. The slides were then removed for transportation and later inspection.

\subsection{Older resins exposed to sea spray}

Existing and largely solidified resin pieces were also collected from the tree trunks and roots (where it had been exposed to the air) in the spray-influenced marginal zones (up to $5 \mathrm{~m}$ from the sea) of the A. columnaris forests in both Grande Terre localities. We removed the resin surfaces from these pieces and placed these on 28 slides for transportation and subsequent observation.

\subsection{Observation and analysis}

All 45 slides (17 from the exposed fresh resin and 28 from solidified resin) were screened under a Carl Zeiss Axio Scope.A1 compound microscope, equipped with a Canon 60D digital camera, differential interference contrast and transmitted light, to examine what objects might have adhered to the resins. Slides with selected objects of interest were then sputtered with platinum-palladium $(2 \times 120 \mathrm{~s}$ at $20 \mathrm{~mA}, 10 \mathrm{~nm}$ coat thickness) using an automatic sputter coater (Canemco Inc.) and examined under a field emission scanning electron microscope (Carl Zeiss LEO 1530 Gemini).

Energy dispersive X-ray spectroscopy (EDX) was performed on crystals found on the resin using an INCAEDX system (Oxford Instruments) and an excitation voltage of $15 \mathrm{kV}$ with this electron microscope. Light microscopic im- 

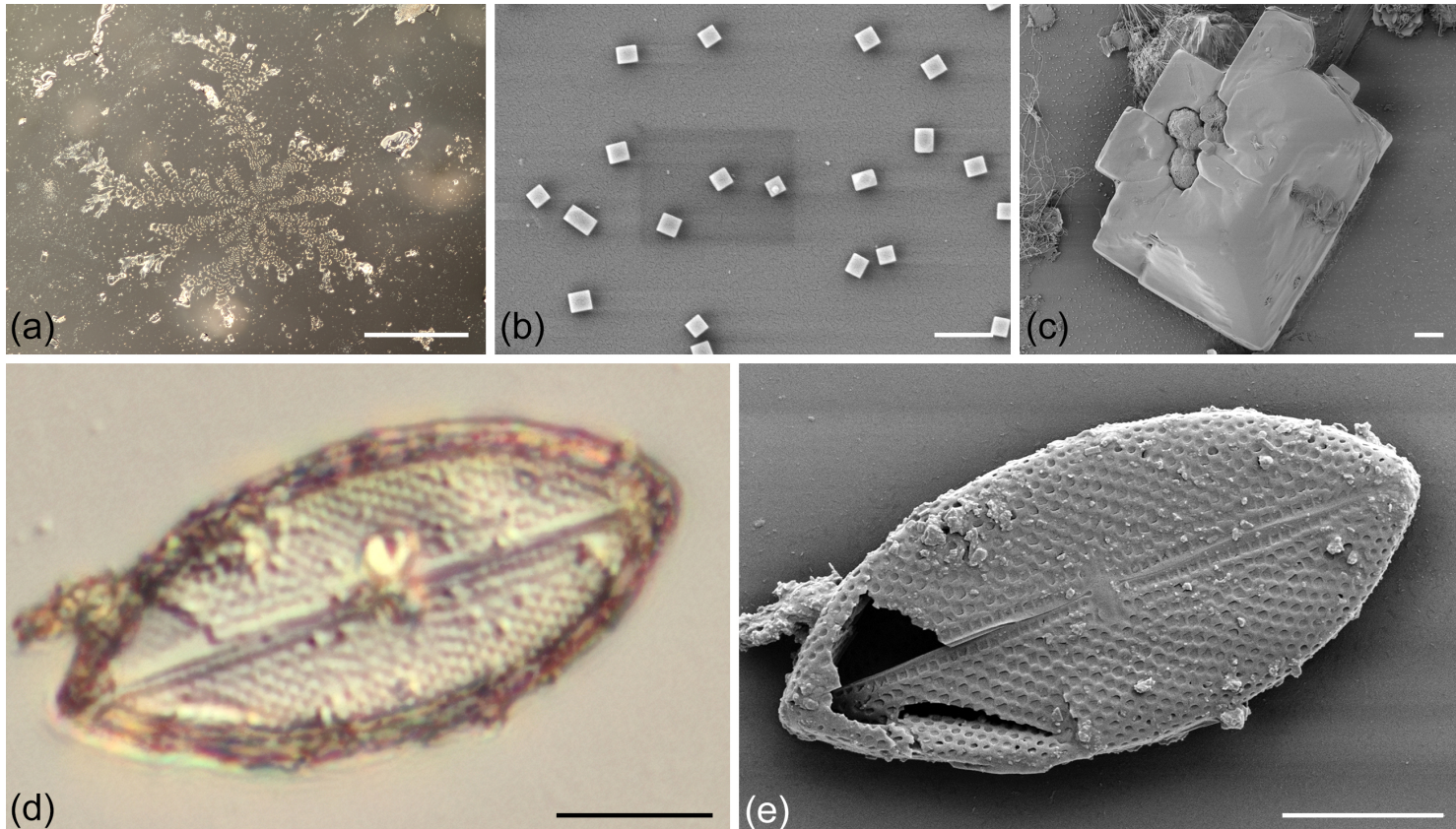

(d)
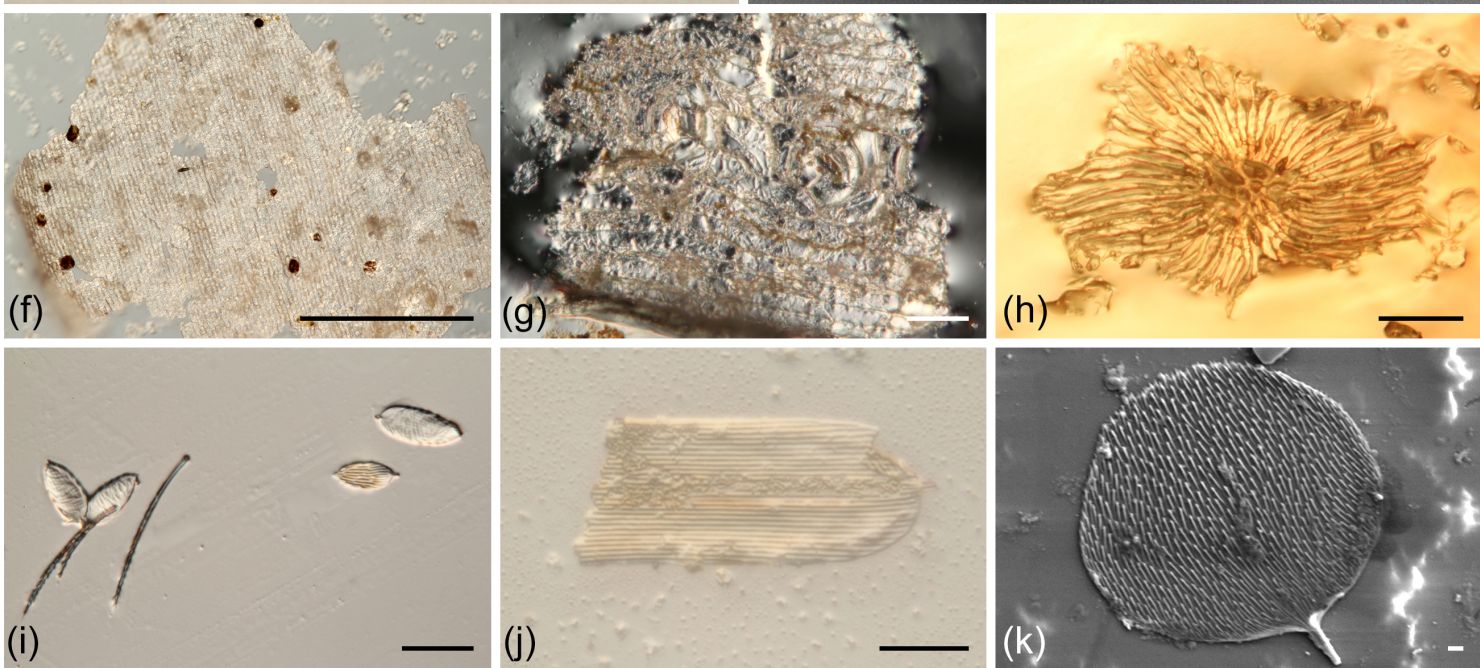

(i)

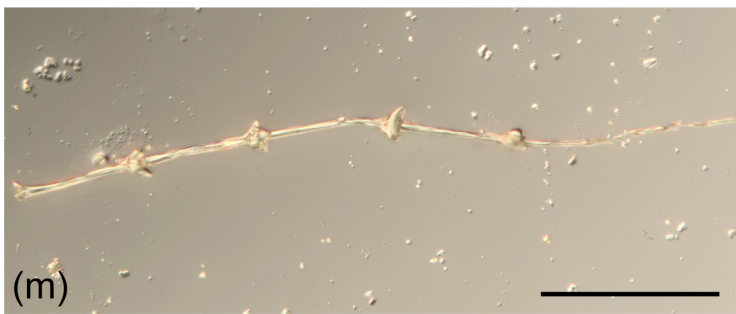

(I)

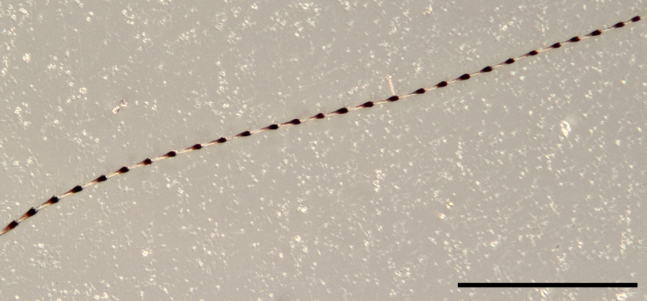

Figure 4. Objects recovered from sea-spray-exposed resins. (a), (d), (f)-(j) and (l)-(m) light microscopy, (b)-(c), (e) and (k) scanning electron micrographs. (a-c) Crystals showing the contact of seawater droplets onto the freshly exposed resins, (a) large sodium chloride "snowflake-like" crystal, (b) small sodium chloride crystals, (c) angular sodium chloride crystal surrounding small calcium sulfate crystals. (d-e) The sole pennate diatom entrapped, Mastogloia sp. (f-h) Plant remains trapped on the resin, (f) Araucaria columnaris cuticle fragment, (g) cuticle fragment with stomata, (h) stellate hair, (i-k) lepidopteran remains (i) several wing scales, (j) wing-scale fragment, (k) complete wing scale, (l-m) feather remnants, pennula with differing node types. Scale bars: $500 \mu \mathrm{m}(\mathbf{a}, \mathbf{f}), 50 \mu \mathrm{m}(\mathbf{g}-\mathbf{i}, \mathbf{l}-\mathbf{m}), 20 \mu \mathrm{m}(\mathbf{j}), 10 \mu \mathrm{m}(\mathbf{c}-\mathbf{e})$, and $1 \mu \mathrm{m}(\mathbf{b}, \mathbf{k})$. 
ages were stacked in Helicon Focus software to give a better three-dimensional representation.

\section{Results}

\subsection{Resin outpourings in the Araucaria columnaris coastal forest sites in New Caledonia}

In all locations observed, many of the trees had produced resin outpourings. The most likely cause of these resinous exudations is "wind rock" causing mechanical stress and rupture of the bark along the length of the trunks which the tree attempts to seal with resin. In a few cases a microbial infection was noted, although we suspect that this is due to a post (wind rock) damage opportunistic infection. In all locations chosen, we observed resin on the tree bark and also on the forest floor (Fig. 3).

\subsection{Fresh resin exposed to sea spray}

Inspection of the slides revealed in most cases the presence of numerous crystals. EDX analysis showed that these crystals consisted of halite (sodium chloride) and occasionally gypsum (calcium sulfate). Both salts are normal components of seawater, indicating that most slides were exposed to sea spray (Fig. $4 \mathrm{a}-\mathrm{c}$ ). The slides also showed a mixture of adhered organic remains mainly belonging to non-marine organisms. However, a frustule of a marine pennate benthic diatom, Mastogloia sp. (Fig. 4d-e), was also recovered. Plant remains found on the slides include cuticle fragments (Fig 4f-g) and stellate hairs (Fig. 4h). Moreover, several different lepidopteran wing-scale remains (Fig. 4i-k) and pennula from birds feathers (Fig. 4l-m) were attached to the resin exposed on the slides.

The Mastogloia frustule (Fig. 4d-e) is $42 \mu \mathrm{m}$ in size and possesses elliptical valves with rounded apices which are covered with areola arranged in a decussate pattern. The raphe slit is slightly undulate in a broad axial area. The central area is rectangular and central nodules are visible. The partectal ring made of equal partecta is closed, forming a continuous ring around the valve margin.

\subsection{Older resins exposed to sea spray}

The older resins in the coastal forests derived from tree trunks and exposed roots (Fig. 3b-c). Observation of slides made from the surfaces of these resin bodies revealed only a few dematiaceous hyphomycetes growing on the resin surfaces (Fig. 5). No other inclusions were found, in contrast to the more diverse collection of adhered organic remains found on the slides of the fresh resin exposed to the sea spray. Conversely, these hyphomycetes were not present on any of the slides of the experimentally exposed resin.
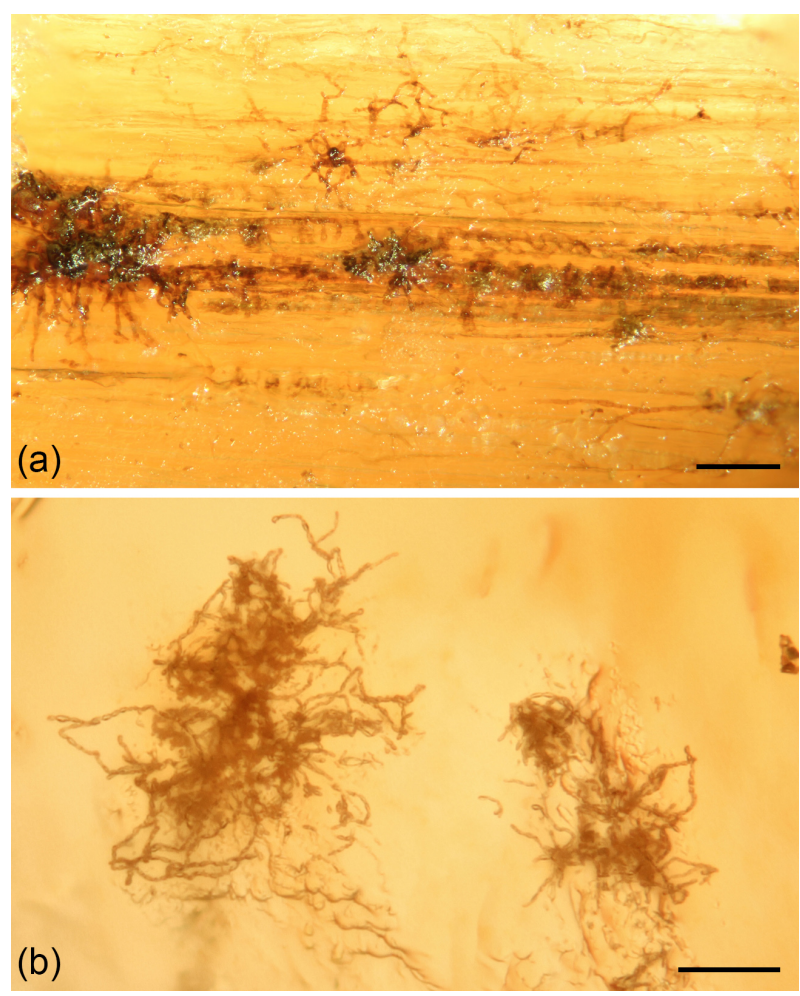

Figure 5. Dematiaceous hyphomycetes growing on naturally occurring resin pieces of Araucaria columnaris in New Caledonia. (a) Mycelium and (b) branched hyphae partly being submerged in resin. Scale bars: $50 \mu \mathrm{m}$.

\section{Discussion}

\subsection{Fresh resin exposed to sea spray}

Our exposure of the fresh resin occurred during a period of non-stormy weather, so "normal" coastal conditions prevailed for the duration of the experiment. Consequently, any particles adhering to the exposed resin must have been windborne or sea-spray-borne. Numerous non-marine organism remains were observed such as plant-derived cuticle and stellate hair fragments, lepidopteran wing scales and fragments from birds' feathers. These non-marine remnants must have been blown by the wind onto the uncured resin surfaces, although some of the plant fragments may have dropped from the forest canopy down onto the slides.

The presence of sea salt crystals found on most experimental slides clearly shows the exposure to sea spray, which then evaporated, before the resin cured. However, despite the clear sea spray exposure, there was only one specimen of a marine organism (one diatom) adhered to the slides. Possibly, the strength of the wind carrying the sea spray was too low to pick up major amounts of marine microorganisms under normal conditions, or the seawater during the experiment did not contain high concentrations of marine microorganisms (no algal blooms were noted at the time of the experiment). 
This potentially implies that it is not the sea spray itself that carries the marine microorganisms - but rather just the wind that blows the organisms onto the resin since none of the amber with marine inclusions reports co-occurring salt crystals. However, we did not add a subsequent resin flow to cover the adhered organic remains, and this could affect the presence of the salt crystals.

\subsection{Older resins exposed to sea spray}

There is a clear difference in the adhered remains found on the fresh resins exposed to sea spray when compared to the surfaces of the older resin bodies. The scarcity of and lack of diversity in inclusions from the latter highlights how rare an event of entrapping biological remains actually is. The older resin bodies may have been exuded under warmer, drier conditions and consequently hardened on the surface before many organic remains could become adhered. Layered resin bodies offer the best chance to find organic remains preserved as the later layers preserve items trapped on earlier layers. The paucity of layered resin bodies found means that any adhered organic remains (whether terrestrial or marine) could have been weathered from the surfaces due to continuous exposure to the elements (sun, rain, seawater).

\subsection{Marine microorganisms in French Cretaceous amber}

Our results reveal the possibility of a wind-driven embedding of marine microorganism remains in tree resins. What is noticeable is that we only had one marine microorganism trapped compared to the higher numbers of marine microorganisms found together in some French Cretaceous amber pieces. This may be due to the low wind strength and/or the lack of an algal bloom (see Sect. 4.1), and the limited number of slides with relatively small amounts of exposed resin in our experiment, which were used to test the possibility of wind-blown marine microorganisms adhering to fresh resin. What we can consequently show is that amber-entrapped marine microorganism remains do not necessarily imply a direct contact of the resin with seawater prior to its curing. Hence, there is no need to invoke a post-storm flooding scenario, nor a mangrove setting, nor a dripping of fresh resin directly into the seawater. Our experiment shows that the adhesion of marine microorganism remnants to resin can occur even at low to moderate winds blowing into resinous coastal forests. It is therefore plausible to find marine microorganism and terrestrial organism residues together in a resin or amber piece. Additionally, studies of the aeolian transport of marine shells shows that even quite large shells (up to $10 \mathrm{~cm}$ ) can be blown inland under certain conditions (see Cadée, 1992). Interestingly, our experiment showed a benthic diatom trapped by the exposed resin, whereas all the diatom taxa described in French amber are planktonic.
Further potential evidence of marine microorganisms being deposited by the wind into the original resin actually comes from the amber pieces themselves. Both Masure et al. (2013) and Saint Martin et al. (2015) reported that some of the marine inclusions (largely dinoflagellates and diatom taxon Corethron) had an aureole or small localised birefringence structure surrounding them. Masure et al. (2013) interpreted these as stress birefringence structures in the amber resulting from the wind-blown dinoflagellates impacting onto the resin in water droplets; then the droplet subsequently evaporated, leaving the visible aureoles in the amber haloing the organisms. Interestingly, neither Masure et al. (2013) nor Saint Martin et al. (2015) report findings of salt crystals in their amber pieces.

When considering the only two reported amber pieces with the high number of dinoflagellate inclusions (ARC 76 and ARC 130 from Charentes; Masure et al., 2013), the question arises as to whether a higher-energy mode of transport rather than just prevailing winds and sea spray - perhaps a storm event - is needed. Given that the dinoflagellates in both pieces occur in large numbers along with insects or terrestrial arthropods on a former resin surface that was covered by subsequent resin flows, the pieces must have been on or very close to the resin source tree. Since resin dropped into water forms pillows, not layers (Schmidt and Dilcher, 2007), the resin must still have remained in the terrestrial realm for the resin layers to build up. Masure et al. (2013) state that "the presence of dinoflagellates in the amber is thought to be the result of a wind-transported concentration from a bloom within water droplets which rapidly evaporated, spraying over the exposed resin from a nearby forest with conifers". From our experimental results, it could be possible that sea spray derived from waters with a higher concentration of marine microorganisms than normal (i.e. a bloom) blown onto fresh resin in a coastal forest could explain the high numbers of dinoflagellates observed in the two pieces of French Cretaceous amber. Hence, a storm or more extreme events (e.g. cyclones, tsunamis) need not necessarily be invoked.

\subsection{Marine macroscopic organisms in Burmese Cretaceous amber}

Smith and Ross (2017) reported a piece of Cretaceous Burmese amber with two pholadid bivalves inside (as well as amber pieces with bivalve borings) that are slightly larger (at $\sim 2 \mathrm{~mm}$ ) than the other marine microorganisms trapped in amber. The only occurrence of a gigantic marine ostracod in amber (almost $13 \mathrm{~mm}$ in length) was also reported from Cretaceous Burmese amber (Xing et al., 2018). This specimen shows that macroscopic organisms larger than previously described microscopic marine organisms are even more exceptional in amber than the already rare microscopic marine inclusions. Xing et al. (2018) reported on an ostracod that was preserved on a resin surface and a subsequent resin flow con- 
taining insect frass and fragments of spiders covered it. They propose that the resin was exuded under or adjacent to water, capturing the ostracod and drying, before a later resin flow containing more forest floor material covered it. Given the potential of aeolian transport of even quite large marine shells (Cadée, 1992), this means that water may not be necessary at this taphonomic step in this specific case and that the dead ostracod was blown onto a forest resin. The bivalves inside Burmese amber, however, are thought to have been bored in (since the potential trace of one boring is preserved) to a resin body that was in or near marine or brackish water; the resin itself would have had a slightly hardened skin but a still liquid centre (Smith and Ross, 2017). This scenario is unique and very different from those proposed for marine inclusions in French Cretaceous amber.

\subsection{Marine macroscopic organisms in Miocene Mexican amber}

Of the diverse inclusions (in particular ostracods, isopods, copepods, crabs and tanaidaceans) in amber recovered from the Campo La Granja amber mines, only the tanaidaceans may represent truly marine macroinclusions (Heard et al., 2018), as the other taxa are interpreted as either semi-aquatic or, if fully aquatic, derived from fresh or brackish waters (Serrano-Sánchez et al., 2015; Huys et al., 2016; MatzkeKarasz et al., 2017; Heard et al., 2018). The assemblage is thought to result from the transport by tides and/or floods to ponds near or at the base of the resin-producing trees (Solórzano Kraemer, 2010; Serrano-Sánchez et al., 2015; Huys et al., 2016; Matzke-Karasz et al., 2017; Heard et al., 2018). Evidence from the open carapaces of many of the ostracods and the extended legs of some of the copepods in the amber is thought to indicate that they were alive on entrapment in the subaqueous soft resin, as the pools they were trapped in dried (Serrano-Sánchez et al., 2015; Heard et al., 2018). The lack of marine microinclusions reported so far from Mexican amber makes comparisons with the French Cretaceous forests difficult, but the potentially subaqueous resin scenario proposed for the Burmese ostracod (see Sect. 4.4, Xing et al., 2018) is similar, although the Burmese amber ostracod was dead on entrapment and so could have been wind-blown into the resin instead, unlike the Mexican ostracods and copepods that were living at the time of their entrapment. Dead macroscopic organisms and moults (as reported by Serrano-Sánchez et al., 2015) may have been blown into the pools or directly onto the exposed soft resin; currently we have no clear way to distinguish exactly how these became entrapped in the Mexican amber.

\section{Outlook}

Our experimental work clearly shows that marine microorganisms can become entrapped in resins of a terrestrial ori- gin, under normal prevailing conditions in coastal forests. It would be interesting to repeat our experiment under stormy conditions and during a time with a marine algal bloom in proximity to the same forests and then compare any adhered objects on exposed resins. It could also be worth checking the forest litter and soil of coastal forests for remains (diatom shells, dinoflagellate cysts, sponge spicules) of marine microorganisms (and macroscopic marine organisms) to understand their frequency and distribution in today's resinous coastal forests, as a guide to similar ecosystems of the past.

Data availability. Slides are deposited at the Department of Geobiology of the University of Göttingen.

Author contributions. ARS, CB, VP, JR and LJS conducted field work. ARS and DG screened the samples. All authors analysed data. ARS and LJS wrote the paper.

Competing interests. The authors declare that they have no conflict of interest.

Acknowledgements. We would like to thank Jérôme Munzinger (Nouméa) and Kerstin Schmidt (Jena) for help in the preparation of our fieldwork in New Caledonia and Gerhard Cadée (Netherlands) for his advice. We are grateful to Dorothea Hause-Reitner (Göttingen) for assistance with field emission microscopy. Fieldwork and collection in New Caledonia were kindly permitted by the Direction de l'Environnement (permit no. 17778/DENV/SCB obtained in November 2011). Partial support for fieldwork was provided to Vincent Perrichot by grant OSUR (Univ. Rennes 1) from programme AO1.P4. Leyla J. Seyfullah was supported by a Dorothea Schlözer fellowship and DFG project number SE2335/3-1.

Edited by: Constanze Bickelmann

Reviewed by: Enrique Peñalver and one anonymous referee

\section{References}

Cadée, G. C.: Eolian transport and left/right sorting of Mya shells (Mollusca, Bivalvia), Palaois, 7, 198-202, 1992.

Coleman, C. O.: Aquatic amphipods (Crustacea: Amphipoda: Crangonyctidae) in three pieces of Baltic amber, Org. Divers. Evol., 4, 119-122, https://doi.org/10.1016/j.ode.2004.01.003, 2004.

Galippe, V.: Recherches sur la résistance des microzymas à l'action du temps et sur leur survivance dans l'ambre, Comptes Rendus de l'Académie des Sciences, Paris, 170, 856-858, 1920.

Girard, V., Schmidt A. R., Saint Martin, S., Struwe, S., Perrichot, V., Saint Martin, J.-P., Grosheny, D., Breton, G., and Néraudeau, D.: Evidence for marine microfossils from amber, Proc. Natl. Acad. Sci. USA, 105, 17426-17429, https://doi.org/10.1073/pnas.0804980105, 2008. 
Girard, V., Néraudeau, D., Breton, G., Saint Martin, S., and Saint Martin, J.-P.: Contamination of amber samples by recent microorganisms and remediation evidenced by MidCretaceous amber of France, Geomicrobiol. J., 26, 121-30, https://doi.org/10.1080/01490450802599268, 2009a.

Girard, V., Saint Martin, S., Saint Martin, J.-P., Schmidt, A. R., Struwe, S., Perrichot, V., Breton, G., and Néraudeau, D.: Exceptional preservation of marine diatoms in upper Albian amber, Geology, 37, 83-86, https://doi.org/10.1130/G25009A.1, 2009 b.

Girard, V., Schmidt, A. R., Struwe, S., Perrichot, V., Breton, G., and Néraudeau, D.: Taphonomy and palaeoecology of mid-Cretaceous amber-preserved microorganisms from southwestern France, Geodiversitas, 31, 153-162, https://doi.org/10.5252/g2009n1a14, 2009c.

Gómez, R. A. and Damgaard, A. L.: A rare diving beetle from Baltic amber: Hydrotrupes prometheus new species reveals former widespread distribution of the genus (Coleoptera, Dytiscidae), J. Paleontol., 88, 814-822, https://doi.org/10.1666/13-017, 2014.

Heard, R. W., Serrano-Sánchez, M. de L., and Vega, F. J. Early Miocene Tanaidacea (Crustacea: Malacostraca) preserved in amber from Chiapas, Mexico, with the preliminary descriptions of new taxa, Neues Jahrb. Geol. Paläontol., 288, 107-120, https://doi.org/10.1127/njgpa/2018/0726, 2018.

Huys, R., Suárez-Morales, E., Serrano-Sánchez, M. de L., CentenoGarcía, E., and Vega, F. J.: Early Miocene amber inclusions from Mexico reveal antiquity of mangrove-associated copepods, Sci. Rep., 6, 34872 https://doi.org/10.1038/srep34872, 2016.

Masure, E., Dejax, J., and De Ploëg, G.: Blowin' in the wind $100 \mathrm{Ma}$ old multi-staged dinoflagellate with sexual fusion trapped in amber: Marine-freshwater transition, Palaeogeogr. Palaeocl., 388, 128-144, https://doi.org/10.1016/j.palaeo.2013.08.008, 2013.

Matzke-Karasz, R., Serrano-Sánchez, M. de L., Pérez, L., Keyser, D., Pipík, R., and Vega, F. J.: Abundant assemblage of Ostracoda (Crustacea) in Mexican Miocene amber sheds light on the evolution of the brackish-water tribe Thalassocypridini, Hist. Biol., 1-36, https://doi.org/10.1080/08912963.2017.1340471, 2017.

Néraudeau, D., Perrichot, V., Batten, D., Boura, A., Girard, V., Jeanneau, L., Nohra, Y. A., Polette, F., Saint Martin, S., Saint Martin, J.-P., and Thomas, R.: Upper Cretaceous amber from Vendée, north-western France: age dating and geological, chemical, and palaeontological characteristics, Cret. Res., 70, 77-95, https://doi.org/10.1016/j.cretres.2016.10.001, 2017.

Nohra, Y. A., Perrichot, V., Jeanneau, L., Le Polles, L., and Azar, D.: Chemical characterization and botanical origin of French ambers, J. Nat. Prod., 78, 1284-1293, https://doi.org/10.1021/acs.jnatprod.5b00093, 2015.

Perrichot, V.: Early Cretaceous amber from south-western France: insight into the Mesozoic litter fauna, Geol. Acta, 2, 9-22, https://doi.org/10.1344/105.000001629, 2004.

Perrichot, V. and Girard, V.: A unique piece of amber and the complexity of ancient forest ecosystems, Palaios, 24, 137-139, https://doi.org/10.2110/palo.2009.S02, 2009.

Perrichot, V., Nel, A., and Néraudeau, D.: Gerromorphan bugs in Early Cretaceous French amber (Insecta: Heteroptera): first representatives of Gerridae and their phylogenetic and palaeoecological implications, Cret. Res., 26, 793-800, https://doi.org/10.1016/j.cretres.2005.05.003, 2005.
Perrichot, V., Nel, A., and Néraudeau, D.: Schizopterid bugs (Insecta: Heteroptera) in mid-Cretaceous ambers from France and Myanmar (Burma), Palaeontology, 50, 1367-1376, https://doi.org/10.1111/j.1475-4983.2007.00721.x, 2007.

Perrichot, V., Néraudeau, D., and Tafforeau, P.: Charentese amber, in: Biodiversity of fossils in amber from the major world deposits, edited by: Penney, D., Siri Scientific Press, Manchester, 192-207, 2010.

Saint Martin, S., Saint Martin, J.-P., Schmidt, A. R., Girard, V., Néraudeau, D., and Perrichot, V.: The intriguing marine diatom genus Corethron in Late Cretaceous amber from Vendée (France), Cret. Res., 52, 64-72, https://doi.org/10.1016/j.cretres.2014.07.006, 2015.

Sánchez-García, A., Peñalver, E., Pérez-de la Fuente, R., and Delclòs, X.: A rich and diverse tanaidomorphan (Crustacea: Tanaidacea) assemblage associated with Early Cretaceous resinproducing forests in North Iberia: palaeobiological implications, J. Syst. Palaeontol., 13, 645-676, 2014.

Sánchez-García, A., Peñalver, E., Bird, G. J., Perrichot, V., and Delclòs, X.: Palaeobiology of tanaidaceans (Crustacea: Peracarida) from Cretaceous ambers: extending the scarce fossil record of a diverse peracarid group, Zool. J. Linn. Soc.-Lond., 178, 492522, https://doi.org/10.1111/zoj.12427, 2016.

Schmidt, A. R. and Dilcher, D. L.: Aquatic organisms as amber inclusions and examples from a modern swamp forest, Proc. Natl. Acad. Sci. USA, 104, 16581-16585, https://doi.org/10.1073/pnas.0707949104, 2007.

Schmidt, A. R., Girard, V., Perrichot, V., and Schonborn, W.: Testate amoebae from a Cretaceous forest floor microbiocoenosis of France, J. Eukaryot. Microbiol., 57, 245-248, https://doi.org/10.1111/j.1550-7408.2010.00471.x, 2010.

Serrano-Sánchez, M. de L., Hegna, T. A., Schaaf, P., Pérez, L., Centeno-García, E., and Vega, F. J.: The aquatic and semiaquatic biota in Miocene amber from the Campo La Granja mine (Chiapas, Mexico): Paleoenvironmental implications, J. S. Am. Earth Sci., 62, 243-256, 2015.

Smith, R. D. A. and Ross, A. J.: Amberground pholadid bivalve borings and inclusions in Burmese amber: Implications for proximity of resin-producing forests to brackish waters, and the age of the amber, T. Roy. Soc. Edin.-Earth, 107, 239-247, https://doi.org/10.1017/S1755691017000287, 2017.

Solórzano Kraemer, M. M.: Mexican amber, in: Biodiversity of fossil amber from the major world deposits, edited by: Penney, D., Siri Scientific Press, Manchester, 42-56, 2010.

Solórzano Kraemer, M. M., Perrichot, V., Soriano, C., and Damgaard, J.: Fossil water striders in Cretaceous French amber (Heteroptera: Gerromorpha: Mesoveliidae and Veliidae), Syst. Entomol., 39, 590-605, https://doi.org/10.1111/syen.12077, 2014.

Xing, L., Sames, B., McKellar, R. C., Xi, D., Bai, M., and Wai, X.: A gigantic ostracod (Crustacea: Myodocopa) trapped in mid-Cretaceous Burmese amber, Sci. Rep., 8, 1365, https://doi.org/10.1038/s41598-018-19877-y, 2018. 